УДК 316.74:37(477.64)

DOI https://doi.org/10.32840/2707-9147.2020.85.12

Я. В. ЗОСЬКА

\title{
СОЦІОКУЛЬТУРНА ЗУМОВЛЕНІСТЬ СПОЖИВАННЯ ОСВІТНІХ ПОСЛУГ У СУЧАСНОМУ УКРАЇНСЬКОМУ СУСПІЛЬСТВІ
}

У статті зазначено, що в умовах постмодернізації українського суспільства відбуваються зміни як у сфері економіки (формується нова філософія бізнесу, нова економіка, ще характеризується переважанням невловимих активів (послуг та технологій)), так $і$ у сфері споживання (за допомогою маркетингу створюються штучні потреби; виробляються нові споживчі цінності та значення; акцент споживчих намірів перекладається на сферу інформації та послуг). Сконцентровано увагу на зростанні суспільної ваги освітніх послуг в умовах формування інформаційного суспільства та на підвищенні уваги споживачів до їх отримання. Звернуто увагу на розуміння освітніх послуг як квазісуспільного блага та їх специфічні властивості як об 'єктів споживання. Вказано, шо рішення споживача не може спиратися на власну оиінку параметрів освітніх послуг через їх специфічність $i$ тому залежить від зовнішньої оцінки та впливу сочіального середовища. Підкреслено, що орієнтацію на сочіальні детермінанти варто розглядати як допомогу в ухваленні рішення споживача, вибору пріоритетів його діяльності та фактори формування ним власних потреб. Підкреслюється, щчо стратегія розвитку ринку може бути побудована не лише на основі знань про внутрішні регулятори споживчої діяльності, а й з урахуванням знань про зовнішні фактори впливу на них. Обтрунтовано, щео вплив зовнішнього впливу можна оцінити лише комплексно, тому необхідн враховувати якомога ширший спектр соціальних факторів впливу.

Зазначено, шо для вивчення та пояснення споживання освітніх послуг як конкретних об 'єктів важливо було б урахувати низку зовнішніх соиіокультурних регуляторів їх діяльності, зокрема, було визначено та описано: інтереси певної иивілізації, усього суспільства, держави, соціальних та референтних груп; цінності, норми, санкиії, мода; смаки, звички, традиції; соціальні ролі, соиіальний статус, спосіб життя споживача як представника певної соиіальної групи; сукупна сочіальна інформація (3МI, реклама, громадська думка тощьо); інновачії; ситуаиійні фактори. Проведений аналіз дав змогу стверджувати, шо споживачі керуються иілим комплексом факторів соціокультурного середовища, вплив яких підсилюється активними діями гравців різних ринків, які використовують маніпулятивні стратегії у 3 МI та агресивний маркетинг. Підкреслено, щьо вплив на споживачів освітніх послуг має системний та комплексний характер, щуо підпорядковується мультипліфакторному ефекту.

Ключові слова: освітня послуга, споживачі, зовнішні регулянти, сочіокультурні фактори.

(C) Зоська Я. В., 2020 
Постмодерна епоха та іiі цінності охопили різні країни світу. Загальні тенденції історико-цивілізаційних процесів відчуває на собі й Україна. Вважаємо, що процес постмодернізації в Україні можна проводити за аналогією з таким процесом на Заході та у розвинутих європейських країнах.

Зміни, що відбуваються в сучасному українському суспільстві, науковці характеризують як багатовекторну трансформацію різних сфер життєдіяльності суспільства. Так, глибокі перетворення в економічній сфері призвели до змін у сфері споживання. Відбулось підвищення уваги до споживання та споживача, оскільки відбулися зміни у філософії бізнесу - виробники перестали розглядати споживача лише як елемент економічного виробництва, вони відчули його владу й визначальне місце у процесі збуту та, відповідно, виробництва товарів та послуг. Тезу індустріального суспільства «Ми виробляємо - Ви споживаєте» було замінено на тезу постмодерного суспільства «Ми будемо виробляти те, що Ви будете споживати».

Орієнтація на споживачів, їх владу над виробниками відбулася завдяки розумінню формули успіху - «Знайдіть потребу та задовольніть їі», яку запропонував американський бізнесмен М. Смолл [7, с. 55]. Втім, активний розвиток маркетингу, реклами призвели до вдосконалення стратегії розвитку бізнесу за рахунок можливості створення штучних потреб споживача (створіть потребу, щоб виникло бажання задовольнити іiі). 3 огляду на це маркетологи все частіше свої основні дії стали фокусувати на створенні штучних потреб споживача та на його спокусі. Як наслідок, формування ринків стало багато в чому залежати від споживачів.

Настання ери постмодерну пов'язане не лише із продукуванням нових цінностей та сенсів споживачів, але й із значним розширенням спектру можливостей задоволення потреб. Так, сфера послуг займає все більш стійкі позиції як у світовому господарстві, так і в сучасній Україні. Об'єктами споживання все частіше стають не тільки товари, але й різноманітні послуги. Збільшення спектру послуг та їх частки у ВВП засвідчує прояв ознак суспільства постіндустріального типу в Україні. Органічним проявом постмодерного суспільства $є$ формування інформаційного суспільства, нової економіки, яка характеризується перевагою невловимих активів (послуг і технологій) і зниженням ролі відчутних активів [16]. «Нова економіка» є прямим наслідком п’ятого технологічного укладу в економіці, основа якого - електроніка, комп'ютерні, космічні і біотехнології, новітні джерела енергії, телекомунікації тощо [6]. За умов нової економіки багатство визначається насамперед володінням гуманітарним капіталом, хоча капітал, вкладений у матеріальні ресурси, не зникає.

Постмодерна модель споживання характеризується тим, що акцент споживчих інтенцій переноситься на інформаційну сферу, сферу послуг, а в речовому споживанні утверджується неотрадиційна модель 
3 характерним намаганням забезпечувати відтворення людини, проте до потреб відтворення включено як елементи символічного споживання, так і потреби у інформаційно-комунікативних та освітніх послугах [10]. Тому стратегія розвитку ринків може бути побудована тільки 3 урахуванням знань про споживачів, як про їхні внутрішні регулятори (цілі, мотиви, потреби, інтереси, цінності, установки й орієнтації, поведінку), так і про зовнішні регулятори (культура, мода, освіта, релігія, система управління, соціальні інститути, групи й спільноти тощо). За цих умов аналіз специфіки споживання послуг як специфічного об'єкту, а також споживання освітніх послуг українців має актуальний характер, оскільки дозволить пояснити вплив зовнішніх регулянтів - соціокультурних факторів на механізми формування соціальних практик споживання різноманітних послуг у сучасному українському суспільстві.

Зростання ролі послуг у постіндустріальному суспільстві, збільшення їх спектру та частки викликало чималу кількість досліджень у світовій та вітчизняній соціології. Так, характерні особливості постіндустріального суспільства розкриті у публікації Д. Белла, Дж. Гелбрейта, В. Іноземцева, М. Кастельса, У. Ростоу та інших. Проблемам розвитку сфери послуг у світі та Україні присвятили свої праці Г. Башнянина, Н. Даниленко, В. Геєць, В. Герасимчук, Е. Лібанова, М. Маниліч, С. Мочерний, І. Михасюк, Л. Панкова, Г. Шутак та інші. До того ж і тема освіти не є новою в соціології. Класики соціологічної думки розглядали іï як соціальний інститут (Е. Дюркгейм і М. Вебер), як соціальну систему (Т. Парсонс, Н. Луман). Необхідно підкреслити, що увага соціологічної професійної спільноти постійно прикута до освіти як соціального інституту і соціальних аспектів вищої освіти: А. Астахова, В. Добреньков, В. Нечаєв, А. Осипов, М. Руткевич, Л. Рубіна, М. Тітма, В. Турченко, Ф. Філіппов, А. Шереги, В. Шубкін, О. Якуба та інші. Наприкінці $\mathrm{XX}$ століття у вітчизняній соціології сформувався значний базис досліджень різноманітних поведінкових рис молоді й студентства завдяки науковим напрацюванням таких вчених, як Н. Побєда, Л. Аза, Є. Головаха, В. Оссовський, М. Чурилов, О. Яременко, С. Макєєв, C. Оксамитна. Значний вклад у вивчення студентства як цілісної специфічної соціальної групи внесли соціологи міста Харків, як-от: В. Арбєніна, В. Бакіров, В. Ніколаєвський, Л. Сокурянська, Л. Хижняк, О. Якуба. Дослідженню мотивації як самостійного багатоаспектного об'єкту дослідження діяльності студентства присвятили увагу Б. Нагорний, М. Яковенко, А. Яковенко. Проблемам трансформації інституту освіти в Україні присвятили увагу у своїх працях В. Астахова, I. Гавриленко, В. Городяненко, Д. Дзвінчук, П. Куделя, В. Луговий, М. Лукашевич, Л. Сіднєв, О. Скідін, А. Фурман та інші.

Незважаючи на вагомий науковий досвід у вивченні інституту освіти, наявних теоретичних та практичних досліджень у межах соціології освіти стосовно соціокультурних зумовленостей споживання освітніх послуг наразі немає. 
Мета статті - визначити та схарактеризувати основні зовнішні регулянти організації споживання освітніх послуг в Україні за умов поширення постмодерних цінностей.

Однією з властивостей сучасного суспільства $є$ поширеність послуг. Аналіз динаміки розвитку сфери послуг в Україні за 2004-2018 pp. свідчить [3]), що останні десятиліття збільшується роль сфери послуг, розширюється спектр пропонованих послуг. Останнім часом зростає і кількість осіб, для яких актуальним завданням (в умовах поширення ідеології інформаційного суспільства) $є$ навчання протягом життя i, відповідно, отримання освітніх послуг.

Так, наприклад, починаючи з 2000 року контингент студентів, що навчаються у закладах вищої освіти, стрімко зростав (див. табл. 1) до 2012-2013 навчального року. Однак поступово вплив зовнішніх факторів відіграв роль у зниженні контингенту студентства закладів вищої освіти в Україні (можливості виїхати на навчання за кордон, необхідність складання 3НО, військові дії у Донецькій та Луганській областях, анексія Криму тощо).

Кількість студентів, що навчаються

Таблиця 1 у вищих навчальних закладах України III-IV рівня акредитації

\begin{tabular}{|c|c|c|c|c|c|}
\hline \multirow{2}{*}{ В Україні } & \multicolumn{5}{|c|}{ На початок навчального року } \\
\cline { 2 - 7 } & $\begin{array}{c}\mathbf{2 0 0 0 /} \\
\mathbf{2 0 0 1}\end{array}$ & $\begin{array}{c}\mathbf{2 0 0 5 /} \\
\mathbf{2 0 0 6}\end{array}$ & $\begin{array}{c}\mathbf{2 0 1 0 /} \\
\mathbf{2 0 1 1}\end{array}$ & $\begin{array}{c}\mathbf{2 0 1 5} / \\
\mathbf{2 0 1 6}\end{array}$ & $\begin{array}{c}\mathbf{2 0 1 8} / \\
\mathbf{2 0 1 9}\end{array}$ \\
\hline Кількість студентів & 700754 & 1415795 & 2418111 & 1605270 & 1522250 \\
\hline
\end{tabular}

Також поступово зростає кількість споживачів послуг освіти за кордоном. Так, за даними дослідників компанії Selectivv, лише у Польщі навчається 35 тисяч українців (55\% кількості іноземних студентів) [22]. Разом з тим зміни на ринку праці призводять до підвищення попиту в українців на отримання освітніх послуг (здобуття другої вищої освіти, перекваліфікацію, підвищення кваліфікації, вивчення іноземної мови, медіа освіти, навчання в університетах третього віку).

Поділяючи думку дослідниці Н. Тихомирової, під освітньою послугою розуміємо надання можливості здобуття освіти, що ймовірно збільшує вартість робочої сили кінцевого споживача цієї послуги та покращує його конкурентоспроможність на ринку праці [21]. Освітні послуги повною мірою можна віднести до категорії «суспільних благ», покликаних задовольняти колективні потреби (підготовка фахівців визначеного профілю для визначеної сфери діяльності та суспільства загалом). Тому споживачами освітніх послуг є не тільки студенти, учні підготовчих відділень, аспіранти, докторанти, вчителі й інші слухачі, але і підприємства, організації та державні установи, що діють на ринку праці і висувають певні кваліфікаційні вимоги до фахівців. 
Отже, освітня послуга є вельми специфічним об'єктом споживання, якому притаманна низка властивостей (квазісуспільне благо, надається комплексно, разом із перетворенням особистості формує людський капітал, не можна виміряти в безпосередньому грошовому еквіваленті, iз високою споживчою цінністю, результат $є$ невизначеним, корисний результат виявляється через тривалий час, якість $є$ мінливою і залежить від професійного та психоемоційного стану учасників освітнього процесу, компоненти мають різну швидкість старіння, елементи багатокомпонентної структури можуть вступати у конфлікт між собою, нематеріальність та невідчутність потребують формалізації параметрів послуги, відкритість до інновацій, незворотні, ментальні та не відчутні, не виконуються заздалегідь і за відсутності споживача, можуть накопичуватись та зберігатися, надання і споживання збігаються у часі, замовлення й сплата завжди здійснюються заздалегідь) [11]. Усі перелічені властивості освітніх послуг визначають механізм ухвалення рішення споживачем в умовах підвищеного ризику. Рішення споживача не може спиратися на власну оцінку параметрів освітніх послуг і тому залежить від зовнішньої оцінки та впливу соціального середовища. Орієнтацію на соціальні детермінанти можна розглядати як допомогу в ухваленні рішення, вибору пріоритетів діяльності та фактори формування потреб особистості. Ефект зовнішнього впливу можна оцінити лише комплексно і тому необхідно розглядати максимально широке коло соціальних факторів впливу.

Для аналізу різних факторів останнім часом частіше використовують результати етнографії, симптоматологї (аналіз явищ за допомогою симптомів, зовнішніх ознак), герменевтики (тлумачення, інтерпретації текстів) та соціології. Соціологія споживання вивчає отримання послуг освіти як соціальний процес задоволення потреб у розмаїтті його зв'язків з соціальними інститутами, явищами, процесами [20, с. 45]. Вченими зафіксовано, що формування потреб і мотивація знаходяться під впливом цінностей та інтересів окремих соціальних груп та суспільства в цілому. 3 огляду на це до кола інтересів дослідника мають увійти взаємовідносини всіх учасників (споживачі, послугодавці, держава) процесу надання / споживання освітніх послуг [9].

Аналіз практики досліджень поведінки споживачів з огляду різних підходів свідчить про єдність у визначенні певного переліку факторів зовнішнього впливу. Дослідники пропонують розглядати такі фактори: культурні цінності, соціальні групи та їх стиль життя, референтні групи й окремо домогосподарства споживачів [2; 5; 13;]. Узагальнюючи здобутки наукової думки, можна зазначити, що за межами інтересів дослідників залишились такі складники культури, як норми та механізми соціального контролю (санкції)), а також недостатньою є увага до впливу моди як соціального процесу. Не окреслено вплив держави та комунікаційні канали, які виступають трансляторами норм, цінностей, інтересів, стилів життя, що притаманні соціальним групам та суспільству. 
Розглянемо вплив цих факторів на прикладах споживання послуг вищої освіти. Культура (цінності, норми, мораль, право, релігія, мода, звичаї, традиції) визначає і встановлює межі індивідуальної поведінки споживача і впливає на функціонування соціальних інститутів, визначає межі оформлення життєвого стилю споживача. У межах одного суспільства, держави ці розходження можуть не мати яскравого виразу, однак у окремих регіонах простежується чітка специфіка моделей споживання на основі культурних цінностей. У цьому контексті варто звернути увагу на необхідності знання культурної специфіки регіону, міста. Наприклад, цінність фахівців з вищою освітою в областях 3 потужним потенціалом виробничої сфери (машинобудування, промисловість) та розвиненою інформаційною інфраструктурою буде вищою за інші області України.

Процес споживання послуг вищої освіти не тільки узгоджується 3 цінностями (суспільства, соціальних груп, ринку праці), але й обов'язково співвідноситься з культурними нормами, що виступають найбільш прямими, безпосередніми регуляторами суспільних відносин і поведінки людей та відіграють значну роль у механізмах спонукання й активізації діяльності.

Особливість соціальних норм визначається їх обов'язковістю, імперативністю правил та вимог, що відображають інтереси суспільства й особистості. Дієвість норм забезпечується наявністю засобів соціального контролю (санкцій). Санкції поділяють на позитивні (схвалення) і негативні (кара) [23, с. 41]. Означена особливість соціальних норм дозволяє їм виступати в ролі важливої ланки механізму соціального управління і регуляції поведінки людей. Тому соціальні норми можуть бути стимулом (згідно з модою) чи навпаки антистимулом елементом гальмування діяльності.

Так, здобуття вищої освіти є нормою для представників сфери інтелектуальної праці, державних службовців, фахівців управління та керівників різних рівнів. Ця вимога закріплена в нормативних документах, має правову силу, є позитивним стимулом. До того ж здобуття вищої освіти - норма сучасної ділової людини (мораль інформаційного технологізованого суспільства) та модна тенденція розвитку покоління. Водночас мода демонструє не тільки використання механізму наслідування іiі тенденцій, а й індивідуалізації кожного споживача у виборі закладу освіти, напряму підготовки, спеціальності, освітньої програми відповідно до схильностей, можливостей тощо. Проте вибір спеціальності може бути здійснено з використанням механізму наслідування - відповідно до модних тенденцій та престижних спеціальностей, напрямів підготовки.

Отже, споживання послуг вищої освіти детермінується комплексом культурних норм, цінностей, регулюється соціальним контролем та відчуває вплив інших компонентів соціального середовища. Вища освіта стає компонентом культурної норми і поступово входить до кола 
звичних цінностей, що значно впливає на життєві орієнтири споживачів цих послуг.

Вибір вищої освіти, зважаючи на вищезазначене, залежить від дії соціальних норм, але зумовлений внутрішньою активністю, специфічною реакцією. Суб’єктивне відображення конкретного значення соціальних норм може бути неадекватним. Так, для молодої особи досить часто важливо здобути вищу освіту, а їі зміст стає другорядним, тому абітурієнти довго вагаються у виборі закладу або спеціальності. Серед студентів $\epsilon$ певна частка незадоволених своїм вибором, яка примушує їх або до зміни фаху, або до марнотратства (по закінченні працюють не за фахом).

Важливим є вибір, що спирається на соціальні норми як мотиви здійснення діяльності. Цей вибір відбувається на двох рівнях - раціональному й емоційному, він є відповідним відображенням ставлення споживача до норм. На раціональному рівні соціальне спонукання до поведінки включає раціональне відображення ситуації, іiі свідому оцінку. На емоційному рівні мотивація поведінки проходить без попереднього логічного осмислення ситуації, іiі наслідків [18]. Подібний вибір варіанта поведінки допускає, що мотивом учинку виступає звичність, стереотипність поведінки в аналогічних ситуаціях. Ідеться тільки про ті звички, що існують як стереотипні норми соціальної поведінки, закріпляють правила, вимоги певної соціальної норми в індивідуальній свідомості і поведінці людей. Такі звичні норми поведінки стають настільки стійкими, що для їх виконання не треба щоразу будувати логічну модель своєї поведінки. У результаті багато вчинків відбувається стереотипно, ніби автоматично.

Прийняття рішення про здобуття вищої освіти більшість випускників шкіл здійснює на раціональному рівні. Але прийняття рішення про дістання повної середньої освіти (10-11 класи) зазвичай передбачає вступ випускників до вищих навчальних закладів. Тому здобуття вищої освіти можна віднести також до безумовних вчинків (стереотипних), які мотивуються на емоційному рівні. Разом $з$ тим стереотипна поведінка $\epsilon$ складною формою діяльності, в якій закріплено навички поведінки відповідно до ціннісних орієнтацій і установок особистості та суспільства. Сказане дозволяє зробити висновок про те, що норми можуть виявлятися як свідомі (оцінні) і як звичні (стереотипні). 3 огляду на зазначене $є$ певні підстави вважати, що здобуття вищої освіти стає звичною, стереотипною поведінкою, а тому не тільки цінністю й нормою українського суспільства, а поступово й звичаєм.

Звичаї - це такі соціальні норми, що сформувалися стихійно чи свідомо, міцно закріпилися в емоційно-психологічній сфері суспільної й індивідуальної свідомості, стійко виявляються в поведінці людей $[19$, c. 155$]$.

Дія звичаїв спирається на емоційно-звичні механізми стереотипних поведінкових ситуацій. Вибір життєвого шляху, пов'язаного з вищою 
освітою, набуває в наш час характеру звичаю. Мотиваційне ядро такої звички молоді може бути інструментальним, тобто це не завжди звичка навчатися, часто це звичка набування ідентифікаційної якості як особи 3 вищою освітою. Як у часи традиційного суспільства звичкою було навчитися читати та писати, так у епоху інформаційного суспільства звичкою стає здобувати вищу освіту. Зміст такої звичної поведінки, відбиває сучасність і відповідає сьогоднішнім, а не минулим соціальним умовам. Через громадську думку й інші фактори підтримується, схвалюється та культивується здобуття вищої освіти як звичаю і навіть новітньої традиції. Поряд 3 цим критично оцінюються і витісняються інші життєві вибори, що не пов'язані з високим рівнем освіти.

Не можна не підкреслити і таку особливість звичаїв і традицій, як їхню здатність зберігатися і відтворюватися в поведінці людей, способі та стилі життя представників різних соціальних груп.

Поведінка споживачів частково визначається системою соціальної стратифікації $[2 ; 13 ; 5 ; 1]$, соціальним статусом людини як представника певної соціальної групи. Позиція особистості в соціальному просторі вимагає від неї виконання певних соціальних ролей, що передбачає узгодження поведінки й діяльності з очікуваннями певного соціального середовища (групи). Це покладає моральні зобов'язання до визначення відповідного стилю життя та практики споживання. Спосіб життя визначається як зразок чи схема, у відповідність до якої люди живуть, витрачають свій час і гроші [5]. Ці схеми побудовані 3 використанням уявлень про функції споживчих цінностей.

Прийоми позиціювання послуг вищої освіти засновуються саме на інформації про бажану відповідність стилю життя певного соціальної верстви, тому побудовані на асоціаціях споживача з визначеним соціальним класом, до якого він належить або прагне належати, тобто базуються або на існуючому, або на бажаному соціальному статусі споживача.

На модель споживчої поведінки значно впливає фактор мобільності в системі соціальних класів. Будь-яка вертикальна мобільність у стратифікаційній системі вимагає зміни споживчої поведінки, навчання новим зразкам споживання. Освіта є одним з важливих факторів вертикальної мобільності. Аналіз поведінки споживачів послуг вищої освіти допомагає визначити привабливі стилі життя й ті соціальні групи, до складу яких прагне увійти сучасна молодь. До того ж аналіз дозволяє визначити долю тих, хто вже входить до складу цих груп та використовує демонстративну (показну) поведінку (підтверджує свій статус та виконує дії відповідно до визначених цим стилем життя), а також тих, хто використовує видиму поведінку (створює ілюзію відповідності групі) або механізм наслідування стилю життя.

Оскільки споживачі 3 різним соціальним статусом схильні вести різний спосіб життя, вони зазвичай мають розбіжності в діяльності, інтересах та думках, а також у використанні ресурсів: часових, фінансових, матеріальних, інтелектуальних. Соціальний статус здебільшого 
впливає на спрямованість діяльності (тотожність, індивідуальність, наслідування), уявлення людей щодо вибору та застосування критеріїв оцінки під час прийняття рішення стосовно навчального закладу, фаху освіти. Елітні соціальні верстви будуть шукати можливість отримати елітну освіту за кордоном, у престижних, коштовних навчальних закладах. Прагнення представників низького рівня соціальної ієрархії полягає у здійсненні вертикальної мобільності за рахунок нарощування культурного капіталу. Їх прагнення відповідати стандартам середнього класу часто вимагає від людей з невисоким статком мобілізувати свої ресурси для надання можливості своїй дитині отримати вищу освіту за рахунок відмови від задоволення інших потреб.

За нинішніх умов трансформації всіх сфер українського суспільства зростає роль і значення соціальної стратифікації в керуванні поведінкою споживачів. Соціально-стратифікаційна система визначається як ієрархічний розподіл суспільства на відносно гомогенні групи, що передбачає також їх розбіжності у відношенні до цінностей та стилів життя [2]. Така система має значення під час розгляду різних видів споживання, оскільки декларує існування набору унікальних зразків поведінки членів кожної страти у сфері споживання.

Для визначення стилю життя та практики споживання певної страти Дж. Кел пропонує звертати пріоритетну увагу на значення таких ознак: вид заняття, персональне виконання, взаємодія, приватна власність, ціннісні орієнтації, класова свідомість [1, с. 683].

Рід занять є одним з кращих індикаторів соціального класу, тому що робота, яку виконує споживач, значно впливає на його стиль життя і $є$ істотною базою оцінки престижу, пошани і поваги. Значною мірою практики споживання залежать від роду зайнятості споживачів.

Персональне виконання розглядається як складник, тому що відбиває статус споживача у групі зайнятості, до якої він належить, визначає його успіху професійному середовищі.

Фактор взаємодії має значення тому, що люди почувають себе комфортно, коли знаходяться в середовищі, що подібне за стилем життя, цінностями, відносинами, звичаями. Кожен член певної групи (класу) асоціює свій життєвий стиль 3 тими зразками поведінки, що прийнятні цією групою. Наявність вищої освіти саме така ознака, що надає людині впевненість у взаємодіях навіть у повсякденних ситуаціях.

Приватна власність - це символ кожної групи. Для їі відображення звичайно використовують демонстративне (показне) споживання, що повідомляє навколишнім статус власника [4; 15]. До предметів споживання, що демонструють статусну позицію, зазвичай відносять одяг, житло, автомобілі, прикраси, годинник, освіту в елітному (статусному) закладі освіти [13].

Ціннісні орієнтації члена визначеної страти відбивають думки, що характерні саме цій групі. Групова свідомість є важливим складником, 
який відображає ступінь поінформованості людей визначеної страти про себе як про унікальну групу зі спільними політичними, економічними інтересами.

Саме ці чинники мають значний вплив на дотримання певного стилю життя та практики використання споживання. Дійсно, структура мотивів вступу до закладів вищої освіти у всіх школярів міста свідчить про домінанту в ментальності саме сучасного, модного стилю життя.

Особливості поведінки споживачів послуг вищої освіти полягають також й у здійсненні інформаційного пошуку та в обробці інформації. Загальний обсяг інформації щодо критеріїв вибору, переваг та конкурентноздатності закладів освіти споживачі отримують, спираючись на інтереси, цінності, потреби окремих соціальних класів, соціальних інститутів, держави й суспільства загалом. На поведінку споживачів значно впливають держава й органи місцевого самоврядування, що встановлюють певні організаційні і нормативні умови процесу споживання. Отже, для розповсюдження соціальної інформації 3 питань отримання освіти паралельно використовують велику кількість джерел та носіїв інформації. Серед них найбільш впливовими є 3МI, громадська думка та групові комунікації $[17 ; 8]$. Зазвичай з огляду на відмінність у стилях життя, інтересах, цінностях, уявленнях, економічному та соціальному капіталах в освіті споживачів використовують різні канали інформування, розробляють й різні механізми впливу.

Оскільки поведінка споживачів формується i реалізується в оточенні інших людей, то до вагомих факторів впливу варто віднести групові комунікації. Споживач періодично вступає у відносини 3 будь-якою групою, одночасно належачи (формально чи неформально) до кількох груп (первинні, вторинні) та відчуваючи персональний вплив інших людей (прямий чи непрямий). Персональний вплив має найбільшу силу, тому що здійснюється особистістю, яка відома споживачеві й викликає у нього довіру. Сила впливу первинних груп набагато відчутніша і значуща, вони зазвичай нечисленні й існують за принципом подібності учасників, характеризуються згодою і мотивацією, тому дозволяють використовувати необмежені контакти. Так, під час вибору закладу, форми й типу освіти споживачі освітніх послуг спираються перш за все на родину, друзів, проте враховують також думки членів інших груп (однокласники, сусіди, члени професійних колективів, товариств тощо).

Водночас на мотивацію споживача освітніх послуг впливають i ті групи, до складу яких він може не належати, але які є позитивно привабливими, - це групи прагнення - референтні (еталонні), чия позиція або цінності використовуються індивідуумом як основа для поведінки [2, с. 108]. Ці групи є еталоном та орієнтиром для поведінки в конкретній ситуації, вони формують стандарти (норми), стилі життя і цінності, що визначають перспективу мислення та поведінки 
людини, зокрема на вибір освіти. Свою майбутню діяльність споживачі освітнього рівня конструюють, спираючись на образи представників середнього класу, вдалих керівників, провідних фахівців, бізнесменів, державних службовців, які здобули вищу освіту та досягли успіху.

Зв'язок споживача з референтними групами нестабільний та нестійкий. На певних етапах життя він може орієнтуватися на різні групи, до того ж варіативні ситуації споживчого вибору підштовхують до вибору неоднакових референтних груп. Тому зміна ситуації і групової приналежності може позначатися на зміні орієнтирів його поведінки. Отже, споживачі освітніх послуг у своєму виборі, як вказує В. Ільїн у роботі «Мотивація та мотиви», можуть покладатись на різні групи, що виконують різні функції: групи прагнення, дисоціативні, інформаційні, самоідентифікаційні, ціннісні й утилітарні [13, с. 84-86].

Перш за все будь-яка діяльність споживачів узгоджується з групою самоідентифікації, впливу якої не можливо уникнути, яка змушує всіх своїх членів діяти відповідно до норм та цінностей групи. Основні принципи - «діяти як усі» та «за традицією».

Але прагнення до кращого або дія відповідно до «зразка» вимагає від споживачів освітніх послуг узгодження питання доцільності здобуття вищої освіти 3 представниками груп прагнення. Останні визначають вектор діяльності, їх стиль життя та поведінка стають зразком та омріяним майбутнім, спонукають наслідувати їхню поведінку та повторювати дії. Представниками груп прагнення можуть бути різні високооплачувані професійні групи, що мають доступ до розподілу ресурсів інформації, влади, забезпечують зростання свого добробуту.

Усвідомлення негативних зразків, які демонструють дисоціативні групи, підштовхують до діяльності за принципом «навпаки» та підсилюють стимул не бути подібним. Цінності й зразки поведінки дисоціативних груп не сприймаються. Аналіз альтернативних шляхів надає впевненості у правильності здійснення вибору. До таких груп можна зарахувати безробітних, представників тих професій, що вимагають виснажливої або кропіткої фізичної праці за невеликої зарплатні.

Додати сенсу в дії споживачів допомагають ціннісна та утилітарна референтні групи. Образи, які презентують публічні особистості, сприймаються споживачами як яскраві носії стилю життя, що приймають і наслідують цінності певної групи. Тому бажання наслідувати i образи, і всю групу збуджує в споживача почуття прагнення до відповідного стилю поведінки.

Утилітарна референтна група, яка має у своєму розпорядженні набір позитивних i негативних санкцій i може нагороджувати чи карати, вимагає узгодження своєї діяльності. Тому дії споживачів освітніх послуг спираються на очікувану поведінку: відповідати стилю життя свого класу (усе оточення, представники групи самоідентифікації - мають вищу освіту), діяти згідно з вимогами ринку праці (майбутні роботодавці) тощо. 
Варто усвідомлювати, що дієвість референтних груп буде проявлятися по-різному завдяки використанню таких типів впливу на споживачів, як: інформаційний; нормативний; ідентифікаційний; ціннісно-експресивний. Підсиленню впливу на споживачів освітніх послуг буде сприяти загальноприйнятна громадська думка, що є оцінним судженням різних соціальних спільнот, в яких відбивається їх відношення до змісту та засобів розв'язання суспільних проблем взагалі і проблем освіти зокрема.

Формуванню громадської думки сприяє безпосередній особистий досвід людей, вплив референтних груп і засобів масової інформації. При цьому ЗМІ мають певні переваги - можуть формувати громадську думку та артикулювати іiі. На загальному тлі недовіри владним структурам вплив 3МІ на формування громадської думки стає більш значимим. Ефективність процесу формування громадської думки залежить від загальної спрямованості стратегії 3МI: маніпулятивної або гуманістичної. Вторгнення ринкових відносин у сферу комунікацій зумовило залежність розвитку діяльності ЗМІ від рекламодавців, бізнесменів та політичних діячів, що своєю чергою позначилось на активному поширенні маніпулятивних стратегій. Бурхливий розвиток маркетингу, реклами та PR дозволили використовувати більш широкий діапазон засобів, способів і методів впливу на споживачів (навіювання, наслідування, зараження, переконання, стереотипи, імідж, «ореол», ідентифікація, 25 кадр, рекламні шоу, соціально-психологічні установки) [14, с. 103-138]. Споживачі як головна рушійна сила виробництва та ринкових відносин перетворились на об'єкт маніпулювання. Споживачі керуються цілим комплексом факторів соціокультурного середовища, вплив яких підсилюється активними діями гравців різних ринків, які використовують маніпулятивні стратегії у 3МІ та агресивний маркетинг.

Паралельно із зазначеними вище факторами на формування діяльності споживача по-своєму впливає процес уведення на ринок нових освітніх послуг - інновацій: нових спеціальностей, форм навчання тощо. Для споживачів інноваційність освітньої послуги пов'язана зі зміною споживчої поведінки. За впливом на споживчу поведінку розрізняють безупинні, динамічно безупинні і проривні інновації. Кожна 3 них по-різному впливає на зміну поведінки споживача. Безупинна інновація вимагає мінімальних змін, оскільки пов'язана 3 певною модернізацією наявних освітніх послуг, наприклад зміна спеціалізації. Динамічно безупинна інновація припускає істотні для споживача зміни, оскільки базується на зміні технологій освітньої послуги, трансформується і з'являється в абсолютно новій якості. Приклад - дистанційна освіта. Проривна інновація припускає зміну поведінки споживача, оскільки відбуваються радикальні зміни номенклатури освітніх послуг. Так, у регіоні засновується новий навчальний заклад чи філія відомого закладу освіти. 
Висновки. Діяльність споживача - це переважно навчена поведінка, оскільки більшість відносин, цінностей, смаків, форм поведінки, переваг, символічних значень і почуттів набувається в процесі соціального пізнання та практики. У процесі навчання споживача міняються його знання, досвід, відносини і поведінка. Величезну роль у цьому відіграє культура, соціальні групи, референтні групи, - i саме вони забезпечують накопичення досвіду споживача через первинні групи - родину і друзів, у закладах освіти. Такий соціальний досвід впливає на вибір стилю життя, до якого прагне споживач, і на тип його поведінки.

Констатуємо, що на формування визначеної моделі поведінки споживачів освітніх послуг як квазісуспільного блага впливає багато суб'єктів учасників цього процесу споживання: суспільство, держава, регіон, населений пункт, установи та організації, професійні співтовариства, соціальні інститути, соціальні групи, референтні групи.

Для дослідження та пояснення споживання освітніх послуг як специфічних об'єктів важливим буде врахування таких зовнішніх соціокультурних регулянтів їх діяльності, як: інтереси певної цивілізації, усього суспільства, держави, соціальних та референтних груп; складники культури (цінності, норми, санкції, мода); смаки, звички, традиції; соціальні ролі, соціальний статус, стиль життя споживача як представника певної соціальної групи; сукупна соціальна інформація (3МI, реклама, громадська думка тощо); інновації; ситуаційні фактори [9].

Вищезазначене дозволяє твердити, що вплив на споживачів, зокрема й освітніх послуг, має системний та комплексний характер, що підпорядковується мультипліфакторному ефекту - у формування своєї поведінки споживачі мають сукупно розглядати всі фактори. Можна стверджувати, що споживачі системно й усвідомлено здійснюють їх аналіз. У різні моменти часу, залежно від соціальної моделі споживання й статусу споживача на перший план виходять ті чи інші фактори впливу, оцінювати і досліджувати які необхідно системно та комплексно. Знання джерел інформації, моделей та механізмів впливу соціального середовища допомагає розкрити соціокультурну специфіку формування поведінки споживачів на ринку освітніх послуг, дає змогу моделювати й прогнозувати його трансформацію.

\section{Список використаної літератури}

1. Endgel J. F., Blackwell R. D., Miniard P. W Consumer Behavior. 8-th ed. The Dryzen Press, 1995. 951 p.

2. Алешина Н.В. Поведение потребителей: Учеб. пособие для вузов. Москва : ФАИР-ПРЕСС, 1999. $384 \mathrm{c}$.

3. Валовий внутрішній продукт за 2018 рік. Сайт Державної служби статистики України. URL: http://ukrstat.gov.ua.

4. Веблен Т. Теория праздного класса. Москва : Прогресс, 1984. 367 с.

5. Гантер Б., Фернхам А. Типы потребителей: введение в психографику / Пер. с англ. под ред. И. В. Андреевой. Санкт-Петербург : Питер, 2001. 304 с. 
6. Григорян А.Л.. На пути к «новой экономике»: концепции инновационного развития России. Государство и общество. Москва, 2005. С. 82-85.

7. Дерюгин В.И. Теневая психология. Москва : Эксмо, 2003. 320 с.

8. Зоська Я.В. Особенности поведения потребителей в сфере высшего образования. Сочиальные технологии. Киев : ГУ «ЗИГМУ», 2004. Вип. 22. С. 117-128.

9. Зоська Я.В. Социологический аспект потребительского выбора и поведения. Проблеми розвитку соиіологічної теорії: Матеріали першої Всеукраїнськ. сочіолог. конф. Київ, 2001. С. 355-359.

10. Зоська Я.В. Послуги та сервіс в постіндустріальному суспільстві: затребуваність у споживанні. Соціальні технологї: актуальні проблеми теорії та практики : зб. наук. пр. Запоріжжя : КПУ, 2014. Вип. 63. С. 35-45.

11. Зоська Я.В., Заставська Л.П. Споживання послуг вищої освіти українською молоддю. Сочіально-економічні, сочіально-педагогічні та сочіально-психологічні проблеми морської освіти : матеріали I Міжнародної науково-практичної конференції (м. Керч, 14-16 червня 2012 р.). Мелітополь, Колор Принт, 2012. С. 21-25.

12. Зоська Я.В. Суспільство споживання та соціальні практики споживачів в Україні : монографія. Запоріжжя : КПУ, 2011. 352 с.

13. Ильин В.И. Поведение потребителей. Санкт-Петербург : Питер, 2000. 224 с.

14. Лебедев-Любимов А.Н. Психология рекламы. Санкт-Петербург : Питер, 2003. 368 c.

15. Лейбенстайн X. Эффект присоединения к большинству, эффект сноба и эффект Веблена в теории покупательского спроса. Теория потребительского поведения и спроса. Санкт-Петербург, 1993. С. 305-307.

16. Новая экономика. URL: http:// http://ru.wikipedia.org/wiki/Новая экономика.

17. Оссовський В.Л. Громадська думка: спроба соціологічної інтерпретації. Київ : Ін-т соціології НАНУ, 1999. 137 с.

18. Пеньков Е.М. Социальные нормы: управление, воспитание, поведение: Монография. Москва : Высш. шк., 1990. 176 с.

19. Социология. Основы общей теории : учеб. для вузов / Отв. ред. Г.В. Осипов, Л.Н. Москвичев. Москва : НОРМА, 2002. 912 с.

20. Тарасенко В.И. Социология потребления: Методологические проблемы. Киев : Наук. думка, 1993. 168 с.

21. Тихомирова H. В. Дефиниции маркетинга образования. URL: http//www.marketing.spb.ru/conf/2002-01-edu/sbornik-5.htm.

22. Щороку в Польщі зростає кількість українських студентів: чим приваблює освіта за кордоном. URL: https://tsn.ua/ukrayina/schoroku-v-polschi-zrostaye-kilkistukrayinskih-studentiv-chim-privablyuye-osvita-za-kordonom-1318044.html.

23. Якуба Е.А. Социология. Учебное пособие для студентов. Харьков : Константа, 1996. 192 с.

\footnotetext{
Зоська Я. В. Социокультурная обусловленность потребления образовательных услуг в современном украинском обществе

В статье указано, что в условиях постмодернизации украинского общества происходят изменения как в сфере экономики (формируется новая философия бизнеса, новая экономика, характеризующаяся преобладанием неуловимых активов (услуг и технологий)), так и в сфере потребления (посредством
} 
маркетинга создаются искусственные потребности; создаются новые потребительские иенности и смысль; акиент потребительских намерений смещается на сектор информации и услуг). Скониентрировано внимание на росте общественного веса образовательных услуг в условиях формирования информационного общества и на повымении внимания потребителей $\kappa$ их получению. Обращено внимание на понимание образовательных услуг как квазиобщественного блага и их спечифические свойства как объектов потребления. Указано, что решение потребителя не может опираться на собственную оценку параметров образовательных услуг через их специфичность и поэтому зависит от внешней оценки и влияния социильной средыл. Подчеркнуто, что ориентацию на сочиальные детерминанты следует рассматривать как помощь в принятии решения потребителя, выбора приоритетов его деятельности и факторы формирования им собственных нужд. Подчеркивается, что стратегия развития рынка может строиться не только на основе знаний о внутренних регуляторах потребительской активности, но и с учетом знаний о внешних факторах воздействия на них. Обосновано, что влияние внешнего воздействия может оцениваться только комплексным образом и поэтому необходимо учитывать как можно более широкий круг сочиильных факторов влияния.

Отмечено, что для изучения и объяснения потребления образовательных услуг в качестве конкретных объектов важно учитывать ряд внешних сочиокультурных регуляторов их деятельности, в частности, были определень и описаны следующие интересы: интересы конкретной циивилизации, всего общества, государства, сочиальных и референтных групп; иченности, нормы, санкции, мода; вкусы, привычки, традиции; социальные роли, сочиальнылй статус, образжизнипотребителякакпредставителяопределеннойсоичиальной группь; совокупная сочиильная информация (СМИ, реклама, общественное мнение и т.д.); инновации; ситуационныле факторы. Проведенный анализ позволил утверждать, что потребители руководствуются иельлм комплексом факторов соииокультурной среды, влияние которых усиливается активными действиями игроков различных рынков, которые используют манипулятивные стратегии в СМИ и агрессивный маркетинг. Подчеркнуто, что воздействие на потребителей образовательных услуг носит системный и комплексный характер, подчиняется мультиплифакторному эффекту.

Ключевые слова: образовательная услуга, потребители, внешние регулянты, сочиокультурные факторы.

\section{Zoska Ya. V. Socio-cultural conditioning of consumption of educational services in modern Ukrainian society}

The article states that in the conditions of postmodernization of Ukrainian society, changes are taking place both in the sphere of economy (new business philosophy, new economy, characterized by the predominance of elusive assets (services and technologies) is formed) and in the sphere of consumption (by means of marketing, artificial needs are created; new consumer values and meanings are produced; the emphasis of consumer intentions is shifted to the information and services sectors). The focus is on increasing the social weight of educational services in the conditions of formation of the information society and on increasing the attention of consumers to receiving them. Attention is drawn to the understanding of educational services as quasi-social goods and their specific properties as objects of consumption. It is stated that the consumer's decision cannot be based on his own assessment 
of the parameters of educational services because of their specificity and therefore depends on the external assessment and influence of the social environment. It is emphasized that orientation towards social determinants should be considered as an aid in the decision making of the consumer, the choice of priorities of his activity and the factors of formation of his own needs. It is emphasized that the strategy of market development can be built not only on the basis of knowledge not only about internal regulators of consumer activity, but also taking into account knowledge about external factors of influence on them. It is substantiated that the effect of external influence can only be assessed in a complex way and therefore it is necessary to consider the widest possible range of social factors of influence.

It was noted that in order to study and explain the consumption of educational services as specific objects, it would be important to take into account a number of external socio-cultural regulators of their activity, in particular, the following were identified and described: interests of a particular civilization, the whole society, the state, social and reference groups; values, norms, sanctions, fashion; tastes, habits, traditions; social roles, social status, lifestyle of the consumer as representative of a particular social group; aggregate social information (media, advertising, public opinion, etc.); innovation; situational factors. The analysis made it possible to confirm that consumers are guided by a whole set of factors of the socio-cultural environment, the influence of which is amplified by the active actions of players from different markets who use manipulative strategies in the media and aggressive marketing. It is emphasized that the impact on consumers of educational services has a systematic and complex nature, which is subject to a multiplier effect.

Key words: educational service, consumers, external regulations, socio-cultural factors. 